\title{
Search for viruses in rheumatoid macrophage-rich synovial cell populations
}

\author{
HELENA HART AND MARY NORVAL \\ From the Department of Bacteriology, University of Edinburgh Medical School, Teviot Place, Edinburgh \\ EH8 $9 A G$
}

SUMMARY The adherent cells remaining after short-term culture of synovial fluid and synovial membrane cells from rheumatoid and non-rheumatoid patients were examined for the presence of a productive virus infection and for various viral antigens. Labelling was carried out with ${ }^{3} \mathrm{H}$-thymidine and ${ }^{3} \mathrm{H}$-uridine followed by sucrose density gradient centrifugation of the culture supernatant. Only in 1 case was there incorporation of ${ }^{3} \mathrm{H}$-uridine into material of density $1 \cdot 21 \mathrm{~g} / \mathrm{cm}^{3}$. Viral antigens were tested for by indirect immunofluorescence with antisera to rubella virus, the retroviruses RD-114 and simian sarcoma associated virus, early adenovirus type 2 antigens, late adenovirus type 2 antigens, SV-40 T antigen, and in 1 case measles virus. No cell showed immunofluorescence with any antiserum except the early adenovirus type 2 antiserum, which stained the cytoplasm of about half the synovial cell cultures, some from rheumatoid and some from non-rheumatoid patients.

A possible viral aetiology of rheumatoid arthritis has been suggested (Denman, 1975; Barland, 1973; Hamerman, 1975; Marmion and Mackay, 1977), but it has not yet been supported by clear experimental evidence. Virological investigations until recently have concentrated on the long-term culturing of fibroblastic cells. These are derived from synovial membranes of fluids and are thought to be either type A or B lining cells (Smith, 1971). These studies included attempted detection of cytopathic and non-cytopathic viruses, viral genomes, and neoantigens, and no evidence was found which implicated any virus (Person et al., 1973; Grayzel, 1973; Norval and Marmion, 1976).

An alternative hypothesis (Talal, 1975; Denman et al., 1976; Marmion and Mackay, 1977; Fundenberg and Wells, 1976) suggests that the primary and central change is in the effector cells of the immune system ( $T$ or B lymphocytes or monocytederived macrophages) and that the rheumatoid process involves a loss of the normal immunoregulatory control rather than a normal immune reaction against an altered target cell such as a virus-infected fibroblast. This loss of immunoregulatory control could be due to a viral infection of the immune effector cells (Messner, 1974).

Recent virological studies on lymphocytes from synovial fluids and membranes have included an

Accepted for publication March 16, 1979

Correspondence to Dr M. Norval examination for retroviruses, but these were not shown to be present by methods such as nucleic acid hybridisation, fusion, and cocultivation with cells permissive for primate retroviruses, immunofluorescence, and radioimmunoassay (Norval et al., 1979; Hart et al., 1979).

The other type of effector cells of the immune system remaining to be subjected to experimental scrutiny is the monocyte derived macrophage. These are the adherent cells present within the first few days of culture of synovial fluids as described by Mackay et al., (1974) which do not seem to multiply and cannot be subcultured. Most often they are overgrown after variable periods of time by the fibroblastic cells. In addition disaggregated synovial membranes yield a heterogeneous mixture of fibroblasts, macrophages, and undifferentiated esterasepositive cells on primary cultures, and again the fibroblasts generally overgrow the other cells. Traycoff et al. (1976) have described methods for identifying the various populations of synovial mononuclear cells on the basis of morphology, sudanophilia, and several cell markers, and they classified such cells into synovial lining cells, monocyte-derived macrophages, monocytes, lymphocytes, and lymphoblasts.

The role of the synovial macrophages in the joint is not clear. It has been suggested that they may be bearing foreign antigens, as antibody dependent lymphocyte cytotoxicity to adherent cells has been 
demonstrated in short-term cultures (Neill, personal communication). It is of interest that macrophagelymphocyte clusters have been described in autologous cell mixtures obtained from the synovial fluid of rheumatoid patients (Hepburn et al., 1974). Webb et al. (1975) showed that such clusters could be formed with heterologous lymphocytes also. This suggested that there may be an antigen on the macrophages towards which the lymphocytes are sensitive, although there was no stimulation of the lymphocytes in these clusters. It is possible that such an antigen may be virally induced or coded.

Thus it was thought worthwhile to examine the synovial macrophages for the presence of a productive viral infection by means of short-term cultures and labelling with ${ }^{3} \mathrm{H}$-uridine and ${ }^{3} \mathrm{H}$-thymidine. In addition these cells were examined for various viral antigens by immunofluorescence.

\section{Materials and methods}

\section{CELL CULTURE}

Synovial fluids from patients with classical or definite rheumatoid arthritis (RA), other forms of inflammatory joint disease, and osteoarthrosis (OA) were treated within 2 hours of extraction from the patient with $80 \mathrm{U} / \mathrm{ml}$ hyaluronidase for $30 \mathrm{~min}$ at $37^{\circ} \mathrm{C}$. The cells were deposited by centrifugation at $800 \mathrm{~g}$ for $10 \mathrm{~min}$ and washed once in Earles-based Eagle's complete medium (EE). Short-term cultures were set up using $1-2 \times 10^{7}$ viable cells $/ \mathrm{ml} \mathrm{EE;} 10 \mathrm{ml}$ into $100 \mathrm{ml}$ flasks for labelling with ${ }^{3} \mathrm{H}$-thymidine and ${ }^{3} \mathrm{H}$-uridine, and $1 \mathrm{ml}$ into each tube containing coverslips $(22 \times 6 \mathrm{~mm})$ for immunofluorescence. Flying coverslips were used to estimate the number of adherent cells, and $1 \mathrm{ml}$ cell suspension was sufficient to prepare 8 coverslips. All cultures were incubated for 3 hours at $37^{\circ} \mathrm{C}$ in air containing $5 \%$ $\mathrm{CO}_{2}$. The non-adherent cells were removed at this stage by washing thoroughly twice in EE.

Synovial membranes obtained at synovectomy were disaggregated within 2 hours of the operation as described by Abrahamsen et al. (1975), and the single cell suspensions were then handled as above.

\section{COUNT OF ACID ESTERASE-POSITIVE}

ADHERENT CELLS

The flying coverslips were fixed in Baker's formol calcium and the acid esterase staining procedure was carried out as described by Mueller et al. (1975). The adherent count (AC) was determined by counting the acid esterase-positive cells (AEPC) on $10 \mathrm{~mm}^{2}$ of the coverslip and calculating as follows:

$\mathrm{AC} / \mathrm{ml}$ cell suspension $=10 \times 13.2 \times 8 \times \mathrm{AEPC}$ count.
VIRUS DETECTION

After washing the cell sheet to remove the nonadherent cells, the flasks were labelled by adding 0 $10 \mathrm{ml} \mathrm{EE}$ containing $5 \%$ fetal calf serum and either $\left(5-{ }^{3} \mathrm{H}\right)$-uridine or (methyl- ${ }^{3} \mathrm{H}$ )-thymidine (Amer- $\frac{\bar{c}}{\frac{}{7}}$ sham), both at a final concentration of $10 \mu \mathrm{Ci} / \mathrm{ml} . \stackrel{\mathbb{\triangle}}{\Omega}$ Incubation was continued for a further 20 hours at $37^{\circ} \mathrm{C}$. On 3 occasions attempts were made to induce a virus by adding cyclohexidimide $(10 \mu \mathrm{g} / \mathrm{ml})$ at same time as the radioactive medium.

Detection of virus in the culture supernatant was $\stackrel{\sigma}{\circ}$ performed as outlined by Norval and Marmion $\frac{0}{2}$ (1976).

\section{IMM UNOFL UORESCENCE}

This was carried out as described previously (Hart $\overparen{G}$ and Marmion, 1977) with coverslips fixed in acetone $\frac{\text { 의 }}{2}$ after the 3 hour incubation. The specific antisera used were all prepared in rabbits and have been $\frac{D}{O}$ described before together with appropriate control anticell sera. They were anti-rubella virus (Thomas $\vec{\bullet}$ strain) grown in $\mathbf{R K}_{13}$ cells (Hart and Marmion, $\stackrel{\circ}{\circ}^{\circ}$ 1977); anti-RD114 grown in $\mathrm{RK}_{13}$, and anti-simian sarcoma virus grown in KNRK cells (Hart et al., 1979); anti-adenovirus type 2 grown in $\mathrm{RK}_{13}$ cells treated with cytosine arabinoside $(10 \mu \mathrm{g} / \mathrm{ml})$ and used early in infection, and anti-adenovirus type $2 \stackrel{\circ}{\varnothing}$

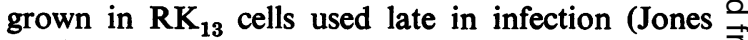
et al., 1979).

In one experiment guinea-pig anti-measles serum (Flow Laboratories) was used. A weak but definitely positive reaction was detected specifically on measles infected Vero cells at $1 / 20$ dilution. This serum was used at 1/10 dilution for the synovial cells. A few immunofluorescent tests also included hamster anti- 3 SV $40 \mathrm{~T}$ antigen serum kindly donated by Dr E. Rogers.

Fluorescein-conjugated anti-rabbit Ig (Wellcome 0 Laboratories) was used at 1/16 dilution: fluoresceinconjugated anti-guinea-pig and anti-hamster (Nordic Diagnostic Laboratories) were used at $1 / 8 \mathrm{~N}$ dilution.

\section{Results}

\section{CULTURE TECHNIQUES}

Cells from synovial fluids or membranes of $14 \stackrel{\circ}{\circ}$ patients with rheumatoid arthritis (RA), 4 with $\stackrel{?}{+}$ osteoarthrosis (OA), 5 with other non-RA conditions, $D$ and 1 undiagnosed were used and the adherent $O$ cell population separated after culturing for 3 hours $\stackrel{\odot}{\Omega}$ at $37^{\circ} \mathrm{C}$. The clinical details are listed in Table $1 . \mathbb{Q}$ In cases where there were sufficient cells, the cultures $\bar{\sigma}$ were labelled with ${ }^{3} \mathrm{H}$-thymidine and ${ }^{3} \mathrm{H}$-uridine, and, after concentration by precipitation with 0 $\left(\mathrm{NH}_{4}\right)_{2} \mathrm{SO}_{4}$, the culture supernatants were analysed 
by sucrose density gradient centrifugation. The acidinsoluble counts per minute in each fraction were determined and plotted against the density of the sucrose to find out if there was a peak of incorporation at any particular density throughout the gradient. As may be seen from Table 1, only in one case, 780127, was there a peak of radioactive insoluble material after labelling with ${ }^{3} \mathrm{H}$-uridine, which occurred at density $1 \cdot 21 \mathrm{~g} / \mathrm{cm}^{3}$. This is shown in Fig. 1. Labelling of the same culture with ${ }^{3} \mathrm{H}$ thymidine did not produce such a peak, supporting the idea that there might have been production of an RNA-containing virus by the adherent synovial cells from this patient. The density, $1 \cdot 21 \mathrm{~g} / \mathrm{cm}^{3}$, is similar to that found on ${ }^{3} \mathrm{H}$-uridine labelling of measles virus produced from Vero cells (Norval and Smith, 1979).

With some synovial specimens there were not sufficient cells to enable the labelling experiment to be carried out, and only immunofluorescence was done.

\section{IMMUNOFL UORESCENCE}

Coverslips containing adherent cells from all the specimens listed in Table 1 were fixed and stained with specific viral antisera to rubella virus, RD-114 (a feline endogenous retrovirus), SSAV (a simian sarcoma retrovirus), and adenovirus type 2 . With the first 3 antisera no specific immunofluorescence was seen, though occasionally there was a nonspecific staining, but this could be easily recognised as the control anti-cell sera reacted similarly. In addition results with the antiserum to the late adenovirus type 2 antigens were uniformly negative. However, with the antiserum to the early adenovirus type 2 antigens about half the specimens examined showed weak uniform non-granular cytoplasmic immunofluorescence, which was not present when the control anti-cell serum was used. This immunofluorescence had no particular pattern being present in the adherent cells from some synovial membranes and some fluids, and from approximately equal numbers of RA patients and non-RA.

Table 1 Clinical and laboratory details of patients whose synovial specimens were used as a source of adherent cells. Results indicating the count of acid esterase positive adherent cells/ml in the population, and labelling of culture supernatants with ${ }^{3} \mathrm{H}$-thymidine and ${ }^{3} \mathrm{H}$-uridine followed by sucrose density gradient centrifugation are shown. In addition immunofluorescence using a variety of viral antisera was carried out on all the specimens

\begin{tabular}{|c|c|c|c|c|c|c|c|}
\hline \multirow{3}{*}{$\begin{array}{l}\text { Case } \\
\text { number }\end{array}$} & \multirow[t]{3}{*}{ Diagnosis } & \multicolumn{2}{|c|}{ Tests for rheumatoid factor } & \multirow[t]{3}{*}{ Specimen } & \multirow{3}{*}{$\begin{array}{l}\text { Count of acid esterase } \\
\text { positive adherent cells } / \mathrm{ml}\end{array}$} & \multicolumn{2}{|c|}{$\begin{array}{l}\text { Labelling of culture } \\
\text { supernatants with }\end{array}$} \\
\hline & & \multirow[t]{2}{*}{$S S C T$} & \multirow[t]{2}{*}{ Latex } & & & & \\
\hline & & & & & & ${ }^{3} H-t$ & ${ }^{3}$ H-uridine \\
\hline 780103 & RA & 128 & . & SM & .. & .. & .. \\
\hline 780104 & RA & 1024 & +++ & $\mathbf{S F}$ & $\because$ & $\ddot{-}$ & $\ddot{-}$ \\
\hline 780105 & $\mathbf{R A}$ & 32 & .. & SF & . & .. & .. \\
\hline 780106 & $\mathbf{O A}$ & & .. & SF & .. & .. & .. \\
\hline \multirow{2}{*}{$\begin{array}{l}780107 \\
780108\end{array}$} & RA & 256 & ++ & SF & .. & - & - \\
\hline & $\begin{array}{l}\text { Psoriatic } \\
\text { arthropathy }\end{array}$ & $<16$ & - & $\mathrm{SF}$ & & & \\
\hline 780109 & RA & .. & .. & SM & $\begin{array}{l}\cdots \\
. .\end{array}$ & 二 & - \\
\hline 780110 & RA & $<16$ & - & SM & .. & - & 二 \\
\hline 780114 & $\mathbf{R A}$ & 64 & ++ & SF & $\cdots$ & - & - \\
\hline 780115 & OA & .. &.. & SM & $3.2 \times 10^{5}$ & - & - \\
\hline 780117 & RA & 16 & .. & SM & & - & - \\
\hline 780118 & $\mathbf{R A}$ & $<16$ & $\dddot{ \pm}$ & $\mathbf{S F}$ & $1.1 \times 10^{5}$ & - & - \\
\hline 780119 & Undiagnosed & .. & .. & SF & $7.5 \times 10^{3}$ & - & - \\
\hline \multirow[t]{2}{*}{780121} & $\begin{array}{l}\text { Bilateral } \\
\text { congenital }\end{array}$ & & 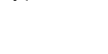 & & & & \\
\hline & dislocated hip & & .. & SM & $1.4 \times 10^{5}$ & .. & .. \\
\hline 780122 & OA & $<16$ & .. & SM & $4.8 \times 10^{4}$ & $\ddot{-}$ & 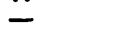 \\
\hline 780123 & RA & $<16$ & ++ & SM & $1.8 \times 10^{4}$ & .. & .. \\
\hline 780124 & Synovitis & $<16$ & - & $\mathbf{S F}$ & $1.5 \times 10^{4}$ & .. & \\
\hline 780127 & $\mathbf{R A}$ & 32 & .. & SM & . & - & $\begin{array}{l}\text { Peak at } \\
\text { density } 1 \cdot 21\end{array}$ \\
\hline 780129 & & & .. & SM & .. & 一 & $\underline{\mathbf{g} / \mathrm{cm}^{3}}$ \\
\hline 780130 & RA & $\ddot{<} 16$ & $\ddot{-}$ & $S F$ & $\ddot{.}$ & .. & .. \\
\hline \multirow{2}{*}{780131} & Psoriatic & & & & & & \\
\hline & arthropathy & $<16$ & - & SF & $9.1 \times 10^{4}$ & 一 & - \\
\hline 780132 & RA & 1024 & .. & SF & $6.7 \times 10^{4}$ & .. & -* \\
\hline 780133 & RA & $<16$ & .. & SF & $4.2 \times 10^{4}$ & - & -* \\
\hline
\end{tabular}

* 780131 and 780133 were also treated with $10 \mu \mathrm{g} / \mathrm{ml}$ cycloheximide at the same time as adding ${ }^{3} \mathrm{H}$-thymidine or ${ }^{3} \mathrm{H}$-uridine; 780132 was treated with cycloheximide at the same time as adding ${ }^{3} \mathrm{H}$-uridine.

$\ldots=$ not tested. $\mathbf{S M}=$ synovial membrane. $\mathbf{S F}=$ synovial fluid. RA =rheumatoid arthritis. $\mathbf{O A}=$ osteoarthrosis. $\mathbf{S S C T}=$ (sensitised sheep cell test)-agglutination of sheep red cells coated with specific rabbit antibody. Latex =agglutination of latex particles coated with IgG globulin. 


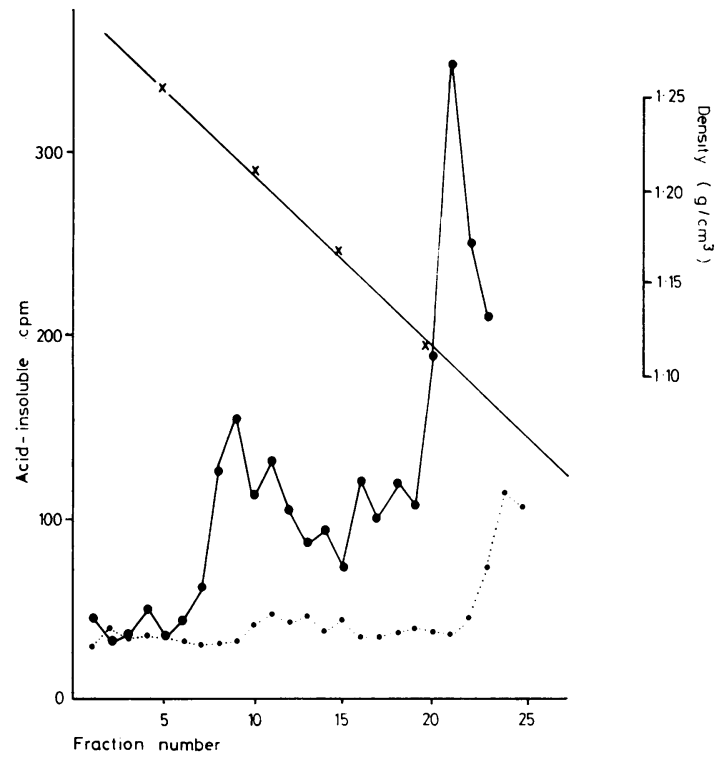

Fig. 1 Acid-insoluble counts per minute in sucrose density gradient fractions from 780127 adherent cell culture supernatant after labelling with ${ }^{3} \mathrm{H}$-thymidine $(\bullet-\cdots)$ and ${ }^{3} \mathrm{H}$-uridine $(\bullet-\bullet)$.

Three cultures, 780131, 780132, and 780133, were also reacted with anti-SV $40 \mathrm{~T}$ antigen serum but with negative results.

Finally, measles antiserum was used on adherent cells from patient 780127 to check whether the peak obtained on sucrose density gradients after labelling with ${ }^{3} \mathrm{H}$-uridine represented productive measles infection. No measles antigens were detected, and no further identification of the material within the radioactive peak was made.

\section{Discussion}

Very little has been published thus far on the properties of the synovial monocyte-derived macropages, though there have been suggestions that they may express unique antigens or phagocytose specific immune complexes and thus may account for the immune processes seen in RA.

Rheumatoid synovial macrophages and lymphocytes were shown to form rosettes or clusters in both autologous and heterologous systems, but, as the lymphocytes were not stimulated by this process, there was no indication from this work that an antigen was present on the macrophage surface towards which the lymphocytes were sensitised (Hepburn et al., 1974). This result was confirmed by Runge (1976), who measured lymphocyte stimulation after culturing synovial macrophages with autologous peripheral blood lymphocytes from RA patients and controls. A small degree of stimulation was observed in the rheumatoid cultures, but this 0 was not significantly different from that observed in $\overline{0}$ non-RA cultures. It was suggested that there may be $\frac{\bar{\sigma}}{\frac{\sigma}{\sigma}}$ non-specific lymphocyte activation by immune $\mathbb{\complement}$ complexes associated with the macrophages rather on than a specific synovial antigen expressed on the macrophages.

On the other hand the work of Neill (personal $\overrightarrow{\vec{\omega}}$ communication) does support the idea that some $O$ rheumatoid synovial cells at very early passes may express unique antigens. These were detected by an antibody-dependent cytotoxicity technique using iv synovial cells of mixed types as targets and auto- $\vec{G}$ logous serum. On subculture, which would eliminate $ु$ the macrophage population, the cytotoxicity became 온 negative. Other work using similar techniques and $\rightarrow$ also giving negative results has involved target $\frac{D}{0}$ synovial cells maintained in culture through several subcultures, so that no macrophages were likely to be present (Griffiths et al., 1976).

In this present study an attempt was made to look for virus production and some viral antigens on the adherent synovial cells remaining after a short-term culture. It was hoped in this way to examine a macrophage-rich population of synovial cells which are eliminated by the usual methods of in-vitro culture. A productive virus infection was not demonstrated apart from one instance in which there was incorporation of ${ }^{3} \mathrm{H}$-uridine into material of density $1 \cdot 21 \mathrm{~g} / \mathrm{cm}^{3}$, the same as measles virus. However, by immunofluorescence using antimeasles serum no measles antigens were expressed on the adherent cells from this patient. The culture was not analysed further.

Further, when the adherent cells were examined by immunofluorescence for rubella virus antigens, retrovirus antigen, SV-40 $\mathrm{T}$ antigen, and adenovirus type 2 late antigens, they were all negative. Thus a unique antigen, induced or coded for by these viruses, was not expressed on the synovial macrophage population. Of course many other virus groups remain, but the ones tested here represent good candidates, being implicated in persistent infections and tumorigenicity.

There was some immunofluorescent staining with antiserum to early adenovirus type 2 antigens in the cytoplasm of the adherent synovial cells from some patients. This did not seem to correlate with the diagnosis of the patient or the type of specimen. It may represent expression of some adenovirus genes in normal human tissue which has been described recently in placentas by Jones et al. (1979), and which is under investigation. 
We thank the surgeons and clinicians at the Princess Margaret Rose Hospital and the Northern General Hospital Hospital and Mrs Leonora Hislop for providing the synovial specimens used in this study.

Grant support was given by the Nuffield Foundation.

\section{References}

Abrahamsen, T. G., Fröland, S. S. ,Natvig, J. B., and Pahle, J, (1975). Elution and characterization of lymphocytes from rheumatoid inflammatory tissue. Scandinavian Journal of Immunology, 4, 823-830.

Barland, P. (1973). Possible relationships between an infectious agent and the immune reactions of rheumatoid synovitis. American Journal of Medicine, 54, 143-147.

Denman, A. M. (1975). The viral theory of connective tissue diseases: a review. Medical Biology (Helsinki), 53, 61-84.

Denman, A. M., Pelton, B. K., Appleford, D., and Kinsley, M. (1976). Virus infections of lymphoreticular cells and autoimmune diseases. Transplantation Review's, 31, 79-115.,

Fundenberg, H. H., and Wells, J. V. (1976). The paradox of immunosuppression: $T$ cell deficiency as the cause of autoimmunity. In Infection and Immunity, p. 549. Edited by D. Dumonde. Blackwell Scientific Publications : London.

Grayzel, A. I. (1973). Uridine incorporation into the media and RNA of cultured rheumatoid synovial cells. Arthritis and Rheumatism, 16, 419-421.

Griffiths, M. M., Smith, C. B., Ward, J. R., and Klauber, M. R. (1976). Cytotoxic activity of rheumatoid and normal lymphocytes against allogeneic and autologous synovial cells in vitro. Journal of Clinical Investigation, 58, 613-622.

Hamerman, D. (1975). Evidence for an infectious etiology of rheumatoid arthritis. Annals of the New York Academy of Sciences, 256, 25-38.

Hart, H., McCormick, J. N., and Marmion, B. P. (1979). Viruses and lymphocytes in rheumatoid arthritis. II. Examination of lymphocytes and sera from patients with rheumatoid arthritis for evidence of retrovirus infection. Annals of the Rheumatic Diseases, in press.

Hart, H., and Marmion, B. P. (1977). Rubella virus and rheumatoid arthritis. Annals of the Rheumatic Diseases, 36, 3-12.

Hepburn, B., McDuffie, F. C., and Ritts, R. E. (1974). The macrophage-lymphocyte rosette. Its increased incidence among cells from rheumatoid synovial fluids. Arthritis and Rheumatism, 17, 1026-1032.

Jones, K. W., Kinross, J., Maitland, N., and Norval, M. (1979). Normal human tissues contain RNA and antigens related to infectious adenovirus type 2. Nature, 277, 274-279.
Mackay, J. M., Panayi, G., Neill, W. A., Robinson, A. Smith, W., Marmion, B. P., and Duthie, J. J. (1974). Cytology of rheumatoid synovial cells in culture. I. Composition and sequence of cell populations in cultures of rheumatoid synovial fluids. Annals of the Rheumatic Diseases, 33, 225-233.

Marmion, B. P., and Mackay, J. M. (1979). Rheumatoid arthritis and the virus hypothesis. In Experimental Models of Chronic Inflammatory Diseases, p. 188. Edited by L. E. Glynn and H. D. Schlumeberger. Springer-Verlag: Berlin, Heidelberg, and New York.

Messner, R. P. (1974). Clinical aspects of T- and Blymphocytes in rheumatic diseases. Arthritis and Rheumatism, 17, 339-346.

Mueller, J., Brun del Re, G., Buerki, H., Keller, H-U., Hess, M. W., and Cottier, H. (1975). Non specific acid esterase activity: a criterion for differentiation of $T$ and $B$ lymphocytes in mouse lymph nodes. European Journal of Immunology, 5, 270-273.

Neill, W. A. (Personal communication). Cell and antibody mediated immune responses against autologous synovial membrane cells in rheumatoid arthritis. Submitted for publication.

Norval, M., Hart, H., and Marmion, B. P. (1979). Viruses and lymphocytes in rheumatoid arthritis. I. Studies on cultured rheumatoid lymphocytes. Annals of the Rheumatic Diseases, in press.

Norval, M., and Marmion, B. P. (1976). Attempts to identify viruses in rheumatoid synovial cells. Annals of the Rheumatic Diseases, 35, 106-113.

Norval, M., and Smith, C. A. (1979). Search for viral nucleic acid sequences in rheumatoid cells. Annals of the Rheumatic Diseases, in press.

Person, D. A., Sharp, J. T., and Rawls, W. E. (1973). A search for viruses and mycoplasmas in connective tissue diseases. Arthritis and Rheumatism, 16, 677-687.

Runge, L. A. (1976). Search for antigen in rheumatoid synovial macrophages. Annals of the Rheumatic Diseases, 35, 133-137.

Smith, C. A. (1971). Properties of synovial cells in culture. Journal of Experimental Medicine, 134, 3065-3125.

Talal, N. (1975). Disordered immunologic regulation and autoimmunity. Transplantation Reviews, 31, 240-263.

Traycoff, R. B., Pascual, E., and Schumacher, H. R. (1976). Mononuclear cells in human synovial fluid. Identification of lymphoblasts in rheumatoid arthritis. Arthritis and Rheumatism, 19, 743-748.

Webb, F W., Baker, M., Weisbart, R., Bluestone, R., and Goldberg, L. (1975). Macrophage-lymphocyte clustering in rheumatoid arthritis. Annals of the Rheumatic Diseases, 34, $38-42$. 